\title{
Кондратенко В.М.
}

Центральноукраїнський державний педагогічний університет

імені Володимира Винниченка

\section{ФОРМУВАННЯ ТА РОЗВИТОК ПАРАДИГМИ АДМІНІСТРАТИВНО-ПРАВОВИХ ЗАСОБІВ ЗАБЕЗПЕЧЕННЯ ПРАВ І СВОБОД ОСІБ 3 ІНВАЛІДНІСТЮ}

\begin{abstract}
У статті проаналізовано нормативно-правові акти й наукові публікації XVIII-XXI cm. з питань публічного захисту людей зі стійкими захворюваннями. 3'ясовано позичії представників адміністративного права щодо ступеня впливу державної влади на соціальні процеси. Аргументується, що адміністративно-правове забезпечення прав і свобод людей з інвалідністю корелювалося залежно від керівної моделі інвалідності. Відстоюється позииія необхідності переходу від соиіальної моделі інвалідності до їі правозахисного варіанта. Запропоновано п'ять основних періодів розвитку наукової й державно-правової думки щзодо адміністративно-правових засобів забезпечення прав і свобод осіб з інвалідністю.
\end{abstract}

Ключові слова: адміністративно-правові засоби, люди з інвалідністю, модель інвалідності, органи публічної адміністрації, права і свободи.

Постановка проблеми. 3'ясування питань адміністративно-правового забезпечення прав i свобод людей зі стійкими порушеннями функцій організму вимагає визначення ключових тенденцій та особливостей історичного становлення й розвитку цього явища, що відобразилося в наукових позиціях різних часів з подальшим юридичних закріпленням. У такий спосіб розширюються межі пізнання, які не обмежуються виключно сучасними підходами до реалізації відповідних суспільних правовідносин, дають змогу охопити грунтовні теоретико-правові напрацювання декількох поколінь учених. Крім того, багаторічна апробація законодавчих положень 3 питань інвалідності сприятиме визначенню шляхів удосконалення процесів нормотворчості й правозастосовної діяльності вітчизняних органів публічної адміністрації щодо реалізації та захисту основоположних прав і свобод та інтересів осіб з інвалідністю на рівні з іншими громадянами.

Аналіз останніх досліджень і публікацій. Окремі аспекти історичного розвитку адміністративно-правового регулювання реалізації та захисту прав і свобод осіб 3 інвалідністю в Україні ставали предметом наукових досліджень низки вітчизняних учених, серед яких на особливу увагу заслуговують наукові публікації й монографічні праці останніх років таких авторів, як І.Л. Булик, С.С. Коханчук, А.М. Куца,
А.М. Мхитарян, О.В. Паровишник, С.Ю. Соболь, А.Л. Терещенко та ін. Поряд із цим недостатньо розглянутими залишається низка напрямів окресленої проблематики, зокрема особливості здійснення забезпечення прав і свобод указаної категорії громадян в окремі періоди становлення вітчизняної державності.

Постановка завдання. Метою статті є дослідження питань становлення та розвитку наукової й державно-правової думки щодо адміністративно-правових засобів забезпечення прав і свобод осіб з інвалідністю в Україні.

Виклад основного матеріалу дослідження. Дохристиянський період характеризується поширенням моральної моделі інвалідності, за якого ці люди сприймалися у вигляді певної кари за недотримання канонів релігійних вірувань древніх слов'ян. Усе змінюється з утворенням Київської Русі та прийняттям християнства, яке пропагувала обов'язкову допомогу всім нужденним. Керівництво стародавньої держави відразу передало соціальні важелі впливу на забезпечення людей $з$ інвалідністю до церкви. Із цього моменту стрімко розвинулася на декілька століть благодійницька модель інвалідності, за якою громадянами зі значними порушеннями здоров'я опікувалися церковні структури, що отримували численні пожертви від різноманітних меценатів, благодійників та інших представників населення 
не залежно від матеріального стану чи соціальноекономічного статусу.

Процеси церковного благодійництва постійно залишалися в полі зору князівської влади, що відобразилося в перших писаних джерелах права [1], насамперед у збірнику стародавнього руського права «Руській Правді» за декількох редакцій, складених у XI-XII ст. ст. Вагоме місце посідали положення, присвячені питанням опіки над окремими категоріями людей. У наступних правових актах закладено фундамент основоположної ідеї щодо відокремлення церкви від держави, розкрито особливості їхньої взаємодії та виконання публічних зобов’язань у соціальній сфері.

Насиченість історичними подіями протягом другої половини XIV ст. - першої половини XVII ст. зумовила входження окремих територій України до складу різних держав. Найбільш прогресивний і сталий характер мали Статути Великого князівства Литовського у трьох редакціях 1529, 1566, 1588 рр. 3 одного боку, аналізований документ суттєво вплинув на розвиток правової системи, задав напрями та засади функціонування публічної влади, а також визначив політикоправову доктрину країни. 3 іншого боку, закріпачив сільське населення, позбавивши юридичних можливостей захистити права. У цей час сформувалося дві форми християнської благодійності щодо людей 3 інвалідністю: а) церковна благодійність; б) світська благодійність. Держава фактично не втручалася в зазначені форми, а також дозволила створення великої кількості монастирів. Вагоме значення мали православні братства - релігійні організації, які виникли наприкінці XV ст. На відміну від монастирів, діяльність братств мала більш різнобічний характер. Поряд iз фінансуванням шпиталів для малозабезпечених i хворих громадян вони організовували школи, друкарні та бібліотеки.

Входження більшості українських земель у другій половині XVII ст. - початку XVIII ст. до складу Російської імперії визначило подальший розвиток публічного забезпечення прав і свобод осіб з інвалідністю з урахуванням специфіки відповідного правового поля. Відбувся перехід від церковного благодійництва до державно-адміністративного варіанта суспільної та приватної опіки. На державному рівні вироблено й упроваджено стратегію боротьби із жебрацтвом і переведення такої категорії людей до спеціальних соціальних об'єктів.

3 процесом відсторонення церковних структур від адміністрування заходів 3 питань підтримки бідних громадян відбувається адміністративна реформа. Її зміст полягав у частковій децентралізації публічної влади, а найголовніше - у функціональному відділенні органів виконавчої влади від судової. Наведене позитивно відобразилося на подальшому розвитку доктрини адміністративно-правового забезпечення прав і свобод людини. Згідно 3 імператорським указом «Установи для управління губерній Всеросійської імперії» від 07.11.1775, запроваджувалися прикази громадського піклування. До сфери їхнього відання належало здійснення управління й нагляду за діяльністю низки соціальних об'єктів, серед яких - богадільні, шпиталі та школи. В аналізований період державно-правова думка доповнилася науковими напрацюваннями лиши на початку XIX ст. Перше монографічне дослідження опублікував А.Д. Стог, який систематизував наявні на той момент відповідні теоретико-правові напрацювання [2]. Вони охоплювали державний, соціальний, політико-правовий та економічний зрізи, а також окрема увага приділена функціонуванню соціальних об'єктів для найбільш незахищених верств населення.

Зі становленням поліцейського права як науки продовжили свій розвиток адміністративно-правові засади забезпечення прав і свобод осіб з інвалідністю. В.Ф. Дерюжинський указував, що державна допомога нужденних не викликає дискусій, однак потребує визначення способів ii надання. Дві різні позиції існували в той час [3, с. 440-442], перша 3 яких заперечує необхідність державного сприяння малозахищеним громадянам. 3 іншого боку, церковна підтримка дискредитувала себе, що вимагає втручання публічної влади з метою підтримки відповідних прошарків населення. Подібну позицію розділяв I.Є. Андріївський, який розвивав концепцію формування адміністративно-правового забезпечення соціального захисту населення, зважаючи на критерій їх поділу за групами бідності й жебрацтва [4, с. 491-493]. Автор розділяв думку, що приватна благодійність не спроможна вирішити проблемні питання таких громадян, а лише державі до снаги визначити й реалізувати прийняті напрями та межі публічної підтримки малозахищених верств населення.

Подальші зміни підходів до адміністративноправового забезпечення соціального захисту населення зумовлені низкою ліберально-демократичних реформ 1861-1874 рр., серед яких на увагу заслуговують скасування феодально-кріпосницької системи та реорганізація органів місцевого самоврядування. Щодо вказаного Б.М. Чичерін 
піддавав критиці наукові позиції західноєвропейських учених, що особисті права людини даються iï від народження. Визначення таких прав залежить від державної влади, яка наділена монопольними можливостями прописувати правила, обов'язкові для виконання всім населення.

Аналізований стан речей безпосередньо вплинув на функціонування приказів громадського піклування по всій країні, зокрема К.А. Мушинський у публікація аргументовано доводив, що ці державні установи вже не спроможні виконувати покладені на них завдання. О.Д. Градовський зауважував, що створення й організація діяльності подібних інституцій соціального захисту має проводитися за узгодженням 3 усіма зацікавленими представниками громадянського суспільства. Виключно владні ініціативи та жорсткі адміністративні підходи закономірно не дають бажаного публічного ефекту [5, с. 200]. Наведені позиції, які підтримувалися значною кількістю вчених того часу, у тому числі В.I. Гер'є, П.I. Георгіївським, Д.А. Дрилем, К.П. Победоносцевим, реалізували в практичній площині за рахунок виведення приказів громадського піклування з підпорядкування Міністерства внутрішніх справ Російської імперії та певної зміни засад організації їхньої діяльності.

Серед новацій діяльності приказів громадського піклування кінця XIX ст. - початку XX ст. стало врахування багаторічної практики соціального забезпечення людей 3 інвалідністю в провідних західних європейських країнах. Окремі вчені, зокрема О.К. Адексар, О.І. Скребицький, C.I. Уманець, наголошували на необхідності посиленого соціального забезпечення людей зі значними порушеннями зору i слуху. По всій країні на початок XX ст. почали функціонувати такі соціальні заклади, які перебували в підпорядкуванні Відомства установ імператриці Марії. Згідно з імператорським указом «Положення про головне управління установ Імператриці Марії» від 28.02.1860 [6], розширено сферу діяльності цієї державної установи.

Одним із перших адміністративістів XX ст., який запропонував розуміння інвалідності, $\epsilon$ A.I. Слістратов. Мова йде про втрату працездатності, що триває більше ніж півроку, якщо вона відбувається не внаслідок нещасного випадку на роботі й до досягнення людиною 70 років. Сдиною формою державної підтримки цієї категорії осіб автор убачав соціальне страхування, що в той час знаходилося в Російській імперії лише на законопроектній стадії [7, с. 76-81]. Отже, 3 такої позиції проблематика людей інвалід- ності лежить у площині трудового права і права соціального забезпечення, де державній владі відводиться роль регулятора суспільних правовідносин за межами адміністративно-правового контексту.

Підтримував наведену позицію М.М. Бєлявський, аргументуючи це тим, що практичний досвід довів тезу, що найкраща форма благодійності - трудова діяльність, яка виховує й дисциплінує нужденного [8, с. 227-228]. У Російській імперії застосовувалося цілковите виключення ідеї соціальної допомоги малозабезпеченим громадянам з боку публічної влади, підтримка має надаватися виключно в приватній формі. Згодом нормотворчі роботи сприяли прийняттю масиву основоположних законів і підзаконних актів [9]. У контексті проблематики людей з інвалідністю на увагу заслуговують деякі з них, зокрема Кодекс законів про працю в УСРР 1922 р. Документ закріплював положення Конституції УСРР 1919 р. щодо обов'язку здійснення трудової діяльності всім населенням країни.

Більша частина наукової спільноти сконцентрувала головні зусилля на вирішенні цієї проблеми. Відповідні дослідження розділимо на три групи, які стосувалися з'ясування таких аспектів: юридичні засади повернення до праці військовослужбовців з інвалідністю (І.І. Алексєєв, С.А. Сиротинський); способи й форми стимулювання людей 3 інвалідністю долучитися до суспільно корисної праці (С.О. Бруштейн, А.Е. Єфімець, А.А. Ротенберг); особливі умови трудової діяльності громадян 3 інвалідністю в окремих сферах народного господарства (Н.Е. Акім, М.М. Болдирев, I.T. Гончарук). Ключовою тезою стало обгрунтування поєднання економічної та медичної моделі інвалідності, що вимагає від суб'єктів владних повноважень сприймати інвалідність синонімічною категорією до терміна «непрацездатність». Вони повинні бути залучені до виконання трудових обов'язків, однак з обмеженням видів праці та сфери професійної діяльності.

Учені-адміністративісти здебільшого також підтримували й розвивали конституційні норми щодо забезпечення основних інтересів лише постійно працюючого населення. А.Ф. Свтихієв схвально ставився до чинної вітчизняної системи соціального забезпечення, зважаючи на порядок фінансування пенсій і допомог, де більшість осіб 3 інвалідністю отримували матеріальну допомогу за залишковим принципом із фондів соціального страхування у вигляді пільг. На думку В.Л. Кобалевського, на державну матеріальну 
підтримку могли претендувати особи з інвалідністю $з$ числа військовослужбовців, які віддали своє здоров'я заради народу й держави, а також сліпі та глухонімі - найтяжчі форми інвалідності, що вимагають постійного стороннього догляду [10, с. 383-385]. Крім того, науковці розділяли позицію радянського законодавця з приводу того, що безкоштовна медична допомога й обслуговування $є$ прерогативою працюючого населення.

Протягом 1960-1980-х pp. низка факторів сприяла розвитку публічних підходів до адміністративно-правового забезпечення прав і свобод людей з інвалідністю. У наукових колах продовжуються напрацювання в межах медичної та економічної моделей інвалідності, які згодом доповнюються дослідженням реабілітаційного спрямування, про що свідчать праці А.В. Левшина, О.Ф. Федорова, Я.М. Фогеля [11] та ін. Зумовлено це було не лише великою кількістю цієї категорії осіб у післявоєнний період, а й галопуючим розвитком промисловості. Численні травмування та каліцтва на виробництві, що призводили до втрати працездатності, вимагали втручання публічної влади у формі їх соціального забезпечення і проведення низки заходів щодо повного або часткового відновлення здоров'я.

Аналізований етап державотворення нашої країни характеризувався суттєвим розвитком науки адміністративного права 3 боку провідних представників цього й суміжних спрямувань, серед яких істотне значення мають роботи таких науковців, як В.Б. Авер'янов, Р.С. Павловський, I.М. Пахомов, В.В. Цвєтков, О.М. Якуба [12]. У працях розкрито правову сутність державного управління, зміст та особливості реалізації адміністративно-правових відносин, аспекти взаємодії органів публічної влади з населенням з питань соціального забезпечення й захисту прав і свобод людини та громадянина.

Проголошення державного суверенітету стало важливим етапом становлення сучасної системи адміністративно-правового забезпечення прав i свобод людей з інвалідністю [13]. Протягом 19902000-х рр. набула широкого розвитку політикоправова модель інвалідності, яка характеризувалася активною участю інститутів громадянського суспільства у відстоюванні конституційних прав і свобод людей з інвалідністю. Свропейські інтеграційні прагнення України зумовили розвиток нормотворчості в цьому ракурсі, що реалізувалося у значній кількості законодавчих і підзаконних актів, які забороняли дискримінацію особи за будь-якими індивідуальними ознаками. Ця пози- ція сприяла визначенню подальших напрямів наукових пошуків представників адміністративного і трудового права, зокрема А.М. Куцої, С.В. Пасічніченко, М.В. Чічкань [14].

Останніми роками численні наукові дослідження щодо адміністративно-правового забезпечення прав і свобод осіб з інвалідністю вказують на важливість дотримання соціальної моделі інвалідності в нашій країні. На цьому акцентують увагу в тому числі такі науковці, як С.С. Коханчук, Л.І. Миськів, А.М. Мхитарян, О.В. Паровишник, Є.Ю. Соболь [15], А.Л. Терещенко. Такі зважені підходи $є$ запорукою сталого розвитку громадянського суспільства й дієвості правозахисної діяльності органів публічної адміністрації. Отже, генеза публічного забезпечення цієї категорії громадян прямо залежала від наукової розробленості цієї проблематики, взаємопов'язана 3 панівною державно-правовою думкою в аналізованій сфері, що охоплює основних п'ять періодів.

Перший період (від найдавніших часів до кінця XVI ст.) характеризується переходом після прийняття християнської віри від моральної моделі інвалідності до благодійницької, яка визначала людей зі стійкими захворюваннями об'єктами співчуття й передбачала широку допомогу їм 3 боку церкви та монастирів 3 мінімальним втручанням органів публічної адміністрації.

Другий період (від першої половини XVII ст. до 20-х рр. ХХ ст.) передбачав перехід до державно-адміністративного варіанта суспільної та приватної опіки. Люди з інвалідністю належали до категорії соціально небезпечних елементів, що потребувало за допомогою вжиття адміністративно-примусових заходів викорінення фактів подачі милостині на території всієї країни, а також вироблення правил і порядку поміщення їх до спеціалізованих соціальних установ і закладів.

Третій період (від 20-х рр. ХХ ст. до 1991 р.) відзначається превалюванням медичної та економічної моделей інвалідності. Зі становленням соціального й адміністративного законодавства набули поширення заходи реабілітаційного характеру. Сформовано теоретико-правові підходи до публічного забезпечення цієї категорії осіб на державному, регіональному та місцевому рівнях відповідними органами влади.

Четвертий період (від 1991 р. до 2011 р.) відзначається впровадженням концепції соціальної захищеності людей з інвалідністю. Завдяки ідеям політико-правової й соціальної моделей інвалідності, які забороняють будь-яку дискримінацію, вироблено сучасну систему адміністративно- 
правових засобів забезпечення прав і свобод осіб 3 інвалідністю.

П’ятий період (від 2011 р. й до сьогодні) ознаменувався формуванням законодавчого та наукового підгрунтя щодо створення необхідних умов, які дають можливість людям з інвалідністю ефективно реалізувати свої права і свободи, заклали ідеї розвитку доктрини правозахисної моделі інвалідності.

Висновки. Адміністративно-правове забезпечення прав і свобод людей з інвалідністю на теренах України корелювалося залежно від переважаючої в певний історичний проміжок часу моделі інвалідності. Мова йде про сукупність державноправових і наукових поглядів на проблематику осіб зі стійкими порушеннями функцій організму, що вироблені на підставі світобачення репрезентативної частини суспільства, сформовані під впливом низки факторів. Ключову роль відігравали такі об'єктивні обставини: а) домінуючі в країні державотворчі, законодавчі, геополітичні, соціально-економічні, культурні й інші процеси; б) ступінь розвитку правових положень, що закріплюють механізм і сукупність гарантій щодо реалізації та захисту прав і свобод людини; в) стан теоретико-правової розробки у сфері публічного управління, адміністративного права й соціального забезпечення; г) напрями державної політики із соціальних і гуманітарних питань; д) сформована громадська думка щодо необхідності меж соціального та юридичного забезпечення прав і свобод різних категорій населення.

Список літератури:

1. Памятники русского права. Москва: Гос. изд. юрид. лит., 1952. Вып. 1: Памятники права Киевского государства / под ред. С.В. Юшкова. 304 с.

2. Стог А.Д. Об общественном призрении в России. Санкт-Петербург, 1818. 526 с.

3. Дерюжинский В.Ф. Полицейское право: пособие. 3-е изд. Санкт-Петербург: Сенат. тип., 1911. 550 с.

4. Андреевский И.Е. Полицейское право: в 2 т. 2-е изд., испр. и доп. Санкт-Петербург, 1874-1876. Т. 1: Введение. Ч. 1: Полиция безопасности. 1874. 648 с.

5. Градовский А.Д. Высшая администрация в России в XVIII ст. и генерал-прокуроры. Санкт-Петербург, 1866. $287 \mathrm{c}$. html.

6. Полное собрание законов Российской Империи [1649-1913 г.г.]. URL: http://nlr.ru/e-res/law_r/content.

7. Елистратов А.И. Административное право. Москва: Тип. И.Д. Сытина, 1911. 89 с.

8. Белявский Н.Н. Полицейское право (Административное право): конспект лекций. 3-е изд., доп. П.: Тип. «Екатерингоф. печ. дело», 1915. 409 с.

9. Полное собрание законодательства CCCP (1917-1992 г.г.). URL: http://www.ussrdoc.com.

10. Кобалевский В.Л. Советское административное право. Харьков: Юрид. изд-во Наркомюста УССР, 1929. $417 \mathrm{c}$.

11. Фогель Я.М. Социальное обслуживание инвалидов и лиц пенсионного возраста. Москва: Юрид. лит., $1980.126 \mathrm{c}$.

12. Якуба О.М. Советское административное право (Общая часть). Киев: Вища школа, 1975. 231 с.

13. База даних «Законодавство України». URL: http://zakon.rada.gov.ua/laws.

14. Чічкань М.В. Правове регулювання соціального захисту інвалідів в Україні: дис. ... канд. юрид. наук: спец. 12.00.05. Харків, 2009. 176 с.

15. Соболь Є.Ю. Діяльність органів публічної влади щодо реалізації і захисту прав та свобод інвалідів: адміністративно-правова теорія та практика: дис. ... докт. юрид. наук: спец. 12.00.07. Запоріжжя, 2015. $546 \mathrm{c}$.

\section{ФОРМИРОВАНИЕ И РАЗВИТИЕ ПАРАДИГМЫ АДМИНИСТРАТИВНО-ПРАВОВЫХ СРЕДСТВ ОБЕСПЕЧЕНИЯ ПРАВ И СВОБОД ЛИЦ С ИНВАЛИДНОСТЬЮ}

В статье проанализированы нормативно-правовые акты и научные публикачии XVIII-XXI cm. по вопросам публичной защиты людей со стойкими заболеваниями. Выяснены позиции представителей административного права относительно степени влияния государственной власти на социальные проиессы. Аргументируется, что административно-правовое обеспечение прав и свобод людей с инвалидностью коррелировало в зависимости от руководящей модели инвалидности. Отстаивается позиция необходимости перехода от социальной модели инвалидности кее правозащитному варианту. Предложены пять основных периодов развития научной и государственно-правовой мысли относительно административно-правовых средств обеспечения прав и свобод лии с инвалидностью.

Ключевые слова: административно-правовые средства, люди с инвалидностью, модель инвалидности, органы публичной администрачии, права и свободы. 


\section{FORMING AND DEVELOPMENT OF PARADIGM OF ADMINISTRATIVE FACILITIES}

PROVIDING OF RIGHTS AND FREEDOMS PERSONS WITH DISABILITY

In the article legal acts and scientific publications of XVIII-XXI are analysed on questions public defense of people with proof diseases. Positions of representatives of administrative law are found out in relation to the degree of influence of state power on social processes. Argued, that the administrative providing of rights and freedoms of people with disability correlated depending on the leading model of disability. Position of transition necessity is defended from the social model of disability to her variant. Five basic periods of development of scientific and legal thought are offered in relation to the administrative facilities of rights and freedoms of persons with disability.

Key words: administrative facilities, people with disability, model of disability, organs of public administration, right and freedom. 